\title{
Connectivist Learning Objects and Learning Styles
}

\section{Esther del Moral, Ana Cernea, and Lourdes Villalustre University of Oviedo, Spain}

\author{
emoral@uniovi.es cerneadoina@uniovi.es \\ villalustrelourdes@uniovi.es
}

\begin{abstract}
The Web 2.0 brought in the use of social tools at a large scale in every area: a transformation which led to redefining the teaching-learning process. In this new context knowledge is distributed over network connections in an uncontrolled way - thus learning consists of recognizing relevant information patterns and constructing new connections. Hence, users become active members of learning communities, bringing in their own social context and committing themselves to the whole learning process.

This article presents a comparison between constructivism and connectivism, which arises in the Social Web framework. It also shows an evolution of the Learning Objects design which is moving from a constructivist perspective to a connectivist one (Siemens, 2005), due to the benefits provided by the Web 2.0 tools, and specifically by social media. These new resources allow learning strategies to transfer through multiple users' connections and enable collaborative knowledge construction within networks. Connectivist Learning Objects (CLOs) emerge as interdisciplinary nodes, which incorporate multiple learning experiences from users within very diverse contexts. Adapting CLOs to users' cognitive diversity enhances both the individual learning and the connective one. This paper presents design guidelines for CLOs, based on didactical methodologies to reinforce their adaptability to students learning styles.
\end{abstract}

Keywords: Connectivist scenarios, Connectivist Learning Objects, learning styles.

\section{Introduction}

This article explains a new model that enables and promotes shared knowledge construction around Learning Objects in the context of connectivist settings. These formulas focus learning either into LOs design and development carried out by users or into LOs collaborative categorization through folksonomies applied to ease their shared use and reuse.

The first section describes the improvements brought in by the new framework in connectivist sets. Connectivism is a Learning Theory

Material published as part of this publication, either on-line or in print, is copyrighted by the Informing Science Institute. Permission to make digital or paper copy of part or all of these works for personal or classroom use is granted without fee provided that the copies are not made or distributed for profit or commercial advantage AND that copies 1) bear this notice in full and 2) give the full citation on the first page. It is permissible to abstract these works so long as credit is given. To copy in all other cases or to republish or to post on a server or to redistribute to lists requires specific permission and payment of a fee. Contact Publisher@InformingScience.org to request redistribution permission.

of the digital age developed by George Siemens (2005) and Stephan Downes (2007a, 2007b), as a result of their recognition of the limitations of the behaviourist and constructivist theory. Connectivism considers the principles of complex networks in order to redefine concepts like the knowledge and learning process; knowledge is distributed over network connections in an uncon- 
trolled way, thus relation patterns can be extracted, and therefore, learning consists of recognizing relevant information patterns and constructing new connections (Siemens, 2006, 2008). In summary, the learning process is characterized by:

- knowledge distribution over networks;

- information pattern discovery;

- the profound influence of network diversity and the strength of its ties;

- the easy adaptation to users' learning styles through multiple connection patterns;

- $\quad$ knowledge transfer facilitated by connections;

- easy assimilation of changes in knowledge domains.

Del Moral and Cernea (2005) defined LOs as minimal learning content units, with self meaning, formed by interactive and multiple format information packages, identifiable through metadata, designed to reach a single learning objective, integrating learning content, assets, activities and evaluations. Their outstanding features were reusability, technical compatibility, adaptability, and durability. However, we are witnessing a LO migration to open content with great flexibility, with a more open design which fits into the new connectivist learning framework.

Currently, connectivist LO (CLO) challenges are built upon encouraging and developing connective learning opportunities through community members' interactions for the purpose of collaborative knowledge construction inside dynamic and flexible virtual scenarios. These new CLOs adopt a didactic methodology that includes activities, such as case studies, collaborative problem resolution, decision making, reflection, multiple analyses interpretation, debates, webquests, and collaborative work, which we explain in the second section. Their added value has been enhanced by the new Connectivist Web tools that allow learners to explore information, learning content, and resources in different ways and suggest multiple applications in different contexts.

We will outline some of the major features of CLOs focusing on their adaptability to users' cognitive diversity within the new learning scenarios. Thus, from a connective point of view, the acquired value by the CLOs allows students to exploit the synergies of all community members so as to contribute to mutual enrichment.

Adapting CLOs to the users' cognitive diversity becomes an ideal occasion for individualizing the educational framework and its learning content into a unique collaborative and global structure. CLOs enable knowledge ecosystems that allow connections between ideas and/or concepts and reflect users' experiences, as they access, manage, internalize, and share information according to their cognitive preferences. Users are enabled to create their own CLOs using different collaborative tools, and thus they become consumers, intermediaries, and producers of learning contents, adapted to their learning styles.

\section{Optimization of the Teaching - Learning Process in the Connectivist Web}

The Connectivist Web emerges within a students' generation marked by downloading and shareware, a generation that learns, works, entertains and expresses itself through open collaborative tools like YouTube, Flickr, GoogleTalk, eMule, Fotolog, and Del.ico (Downes, 2005). From this point of view, the social context provided by connectivism promotes new learning activities developed under a collaboration framework:

- Collection: store data, organize resources, filter information, and create new contacts.

- Reflection: think critically, choose and review information, set up new learning itineraries. 
- Connection: spontaneously form working groups, integrate oneself into existing learning communities, share learning objectives, values and attitudes, link information.

- Publication: share learning experiences, edit content in a large variety of formats, convert collaborative tools into cognitive tools.

Learning in connectivist frameworks takes as its starting point the constructivist learning theory described by various authors such as Duffy and Cunningham (1996) or Wilson (1996), who underline that knowledge is constructed through information networks generated by users' communities. In other words, connectivism reformulates constructivism principles at the level of networks and connections. Based on their work, a comparison between constructivism and connectivism is given in Table 1.

Table 1: Constructivism versus Connectivism

\begin{tabular}{|c|c|c|}
\hline & Constructivism & Connectivism \\
\hline Learning is... & $\begin{array}{l}\text { Knowledge and concepts creation by } \\
\text { recognizing relationships between } \\
\text { prior knowledge or experience and } \\
\text { new information. } \\
\text { Social process where knowledge is } \\
\text { constructed from personal experi- } \\
\text { ences of the members of a commu- } \\
\text { nity of practice. } \\
\text { Learner centered process knowledge } \\
\text { and truth are constructed by people } \\
\text { and do not exist outside the human } \\
\text { mind (Duffy \& Jonassen, 1992). }\end{array}$ & $\begin{array}{l}\text { Focused on creating connections be- } \\
\text { tween specialized information sets. The } \\
\text { connections that learners make are more } \\
\text { important than their current state of } \\
\text { knowledge. } \\
\text { A process that occurs in uncertain envi- } \\
\text { ronments of shifting core elements, } \\
\text { where chaos derived from the creation } \\
\text { of spontaneous and uncontrolled con- } \\
\text { nections could contain the meaning. } \\
\text { A process of patterns recognition } \\
\text { through information networks. } \\
\text { Is the sum of others' experiences and } \\
\text { knowledge can reside outside of our- } \\
\text { selves (Stephenson, 1998). }\end{array}$ \\
\hline & $\begin{array}{l}\text { Interaction between learners and en- } \\
\text { vironments. } \\
\text { Activities should be related to learn- } \\
\text { ers' prior experiences. } \\
\text { Meaningful activities anchored in } \\
\text { meaningful context - as memory is } \\
\text { not a context independent process- } \\
\text { (Ertmer \& Newby, 1993): problem } \\
\text { solving and critical thinking. } \\
\text { Testing approaches based on their } \\
\text { prior knowledge and by applying } \\
\text { them to new situations. } \\
\text { Social interactions in communities of } \\
\text { practice (Brown \& Duguid, 1991). }\end{array}$ & $\begin{array}{l}\text { The primacy of the connection at three } \\
\text { levels: neural, cognitive/conceptual, and } \\
\text { social. } \\
\text { Learning network creation and integra- } \\
\text { tion: continual expansion of knowledge. } \\
\text { New and novel connections open new } \\
\text { worlds and create new knowledge. } \\
\text { Generating meaning by conceptual con- } \\
\text { nections. } \\
\text { Experiencing social networks in our } \\
\text { daily life. } \\
\text { Autonomy, diversity, openness and in- } \\
\text { teractivity and connectivity as property } \\
\text { of networks. }\end{array}$ \\
\hline
\end{tabular}




\begin{tabular}{|c|c|c|}
\hline & Constructivism & Connectivism \\
\hline $\begin{array}{l}\text { Learning is in- } \\
\text { fluenced by }\end{array}$ & Activity; Concept; Context & $\begin{array}{l}\text { Complexity: rapid changes core and } \\
\text { diverse knowledge sources. } \\
\text { Diversity of network } \\
\text { Chaos } \\
\text { Complexity and self - organization }\end{array}$ \\
\hline Memory & $\begin{array}{l}\text { Knowledge representation is an im- } \\
\text { portant issue. } \\
\text { Memory is always under construc- } \\
\text { tion, a continuous process of cumu- } \\
\text { late interactions and representative } \\
\text { experiences. }\end{array}$ & $\begin{array}{l}\text { The brain doesn't hold chunks of in- } \\
\text { formation and knowledge anymore, it is } \\
\text { networked. } \\
\text { It is more important to know how to } \\
\text { access knowledge by patterns recogni- } \\
\text { tion and connection making than to } \\
\text { maintain knowledge facts. } \\
\text { Adaptive patterns }\end{array}$ \\
\hline $\begin{array}{l}\text { Learning Con- } \\
\text { tents }\end{array}$ & Try to adapt to mental schemes & Total open design \\
\hline Instruction & $\begin{array}{l}\text { The design process is recursive, non- } \\
\text { linear, and sometime even chaotic } \\
\text { Planning is reflective, and collabora- } \\
\text { tive. } \\
\text { Objectives emerge from design and } \\
\text { development work } \\
\text { General Instructional Design are not } \\
\text { always required. } \\
\text { Instruction emphasizes learning in } \\
\text { meaningful contexts } \\
\text { Scaffolding provided } \\
\text { Formative evaluation is critical } \\
\text { Subjective data may be the most } \\
\text { valuable. }\end{array}$ & $\begin{array}{l}\text { The design process is based on chaos } \\
\text { and complexity theory, theory of emer- } \\
\text { gence and self-organization. (Siemens, } \\
\text { 2005). Based on connective and emer- } \\
\text { gent learning. } \\
\text { There are multiple objectives - all de- } \\
\text { fined by individual pursuit of personal } \\
\text { objectives, but all inter-related through } \\
\text { complex emergent self-organized net- } \\
\text { works and communities. } \\
\text { Cooperation within networks and col- } \\
\text { laboration within groups and personal } \\
\text { learning emerge as self-organizing phe- } \\
\text { nomena rather than imposition by out- } \\
\text { side bodies } \\
\text { Evaluation is secondary to learning, } \\
\text { Peer evaluation emerges from interac- } \\
\text { tion, conversation and negotiation. }\end{array}$ \\
\hline
\end{tabular}




\begin{tabular}{|c|c|c|}
\hline & Constructivism & Connectivism \\
\hline $\begin{array}{l}\text { Learning Envi- } \\
\text { ronments }\end{array}$ & $\begin{array}{l}\text { A central strategy for building con- } \\
\text { structivist learning environment such } \\
\text { as situated learning, multiple per- } \\
\text { spectives and flexible learning is to } \\
\text { create a collaborative learning envi- } \\
\text { ronment } \\
\text { Flexible, provide multiple learning } \\
\text { itineraries, adapted to learners learn- } \\
\text { ing styles. } \\
\text { Based on Internet, accessible any- } \\
\text { where and anytime, portable } \\
\text { Promote social communication and } \\
\text { collaborations } \\
\text { Provide scaffolding: through feed- } \\
\text { back, help, learning guides, peer to } \\
\text { peer, etc }\end{array}$ & $\begin{array}{l}\text { Open to incorporate new users and new } \\
\text { learning resources, enabling the con- } \\
\text { tinuous change of the network structure. } \\
\text { Multiple learning itineraries derived } \\
\text { from the learning community's syner- } \\
\text { gies. } \\
\text { Based on collaborative tools, enhancing } \\
\text { group work and knowledge creation } \\
\text { from community members' experi- } \\
\text { ences. } \\
\text { They also provide tools for manipulat- } \\
\text { ing resources and ideas and to represent } \\
\text { knowledge. } \\
\text { Provide autonomy, diversity, openness } \\
\text { and interactivity and connectivity as } \\
\text { property of networks } \\
\text { Don't provide scaffolding, students help } \\
\text { emerges from the dynamic of the net- } \\
\text { work which brings solutions and depu- } \\
\text { rates errors. }\end{array}$ \\
\hline Learner & $\begin{array}{l}\text { Is central to the learning process } \\
\text { Engaged with the learning process, } \\
\text { providing a rich context within where } \\
\text { ways of understanding can emerge } \\
\text { and evolve (Hannafin, Hannafin, } \\
\text { Land, \& Oliver, 1997) }\end{array}$ & $\begin{array}{l}\text { Is central to the learning process } \\
\text { Has the absolute control over the learn- } \\
\text { ing process, decides on the learning } \\
\text { strategies he would adopt, according to } \\
\text { his own learning style. } \\
\text { Develops the capacity to form connec- } \\
\text { tions between sources of information, } \\
\text { and therefore create useful information } \\
\text { pattern, is required to learn in our } \\
\text { knowledge economy (Siemens, 2005) } \\
\text { Required skills: synthesize and recog- } \\
\text { nizing relevant information patterns. }\end{array}$ \\
\hline
\end{tabular}

\section{Connectivist Learning Objects (CLOs) - More Than Learning Content}

Within this new learning context, marked by a high connectivity between users and resources, by a total opening and by a permanent evolution of the construction of shared knowledge, a new generation of LOs arises, defined by the following features:

- They are more than learning facts; they become guides of "how to acquire knowledge".

- They generate meaning by including the three vital factors which facilitate meaningful learning: activity, concept and context. 
- They generate connections at the three levels: neural, conceptual and social, this way becoming important nodes of learning and social networks, part of our everyday life.

- They incorporate collaborative and connectivist tools based on emergent technologies.

- They possess an open design which allows their edition by all community's members and therefore they are adapted to continuous evolution, dynamic.

- They are part of totally open information systems.

- They become connection vertices between specialized information networks.

- They represent interdisciplinary nodes, since they incorporate multiple learning experiences in many different contexts.

\section{CLOs: Value-Added by Connectivist Learning Sets}

The concept of LOs as "learning pills" emerged more than a decade ago from the necessity of finding a design formula for learning content online that could facilitate learning and knowledge generation. Their ability of adaptation to the specificity of learners' mindsets was the quality that distinguished them from any other digital documents. The information they carried could be easily accessed, retrieved, and activated by learners and, therefore, could be repurposed in order to answer users' needs in a contextual way.

LOs differentiate themselves from conventional digital resources by facilitating mental representations for users since their relevant content can activate analyzers that learners have previously stored in their memory. LOs help students to develop their capacity of abstraction and their ability to synthesize key meanings. Moreover, they stimulate acquiring and integration of new knowledge leaning on existing mental schemes and they facilitate the retrieval of stored knowledge.

Recently a new version of LOs has emerged: Connectivist Learning Objects (CLOs). This new version of LOs activates the three types of learning through cognitive schemes that Rumelhart and Norman (1985) described: aggregation, restructuring, and adjustment. CLOs bring forward a generative learning model - defined by Wittrock (1974) - whose fundamental premise starts out from students' capacity of creating their own meaningful learning context, by generating perceptions and meanings from new experiences consistent with their previous mental schemes.

One of the principles objections to traditional LOs was their lack of learning context, since too much personal context would have limited their transferability and reusability across a broad range of users and learning situations, as showed the Reusability Paradox (Wiley, 2004). In the connectivist picture, CLOs bring meaningful learning context by incorporating users' annotations, comments, and tags, testimony of real learning experiences, which increase the number of connections, and therefore their reusability.

CLOs, as nodes of social networks, propitiate learning from a sociocultural point of view, becoming social mediators, proposing social collaborative activities, and providing P2P feed-back.

Another great promise of LOs was their durability over time and their total independence of platform. These facts generated a rigid design theory based on standards very difficult to achieve and which made LOs less reusable. Their administration in repositories and data bases was achieved by adding metadata according to standards suggested by the authors themselves and required advanced informatics skills. Annotea was one of the first projects to replace this rigid way of managing web resources by incorporating collaborative metadata generated from users' annotations and tags (Koivunen \& Swick, 2003).

The emergence of CLOs has generated new forms of participation which enable new connections and bring in new learning resources, promoting collaboration and teamwork, where users assume different roles according to their own cognitive preferences. Therefore, another feature that characterizes CLOs is their adaptability to students' learning styles. Thus, learners with an active style 
will tend to lead projects, assuming much of the responsibility, while those with a pragmatic style will emphasize the applicability of the activities proposed by the CLO.

Both CLOs and the digital resources they include integrate users' metadata and annotations, as we can see below in the Flickr photo presented in Figure 1:

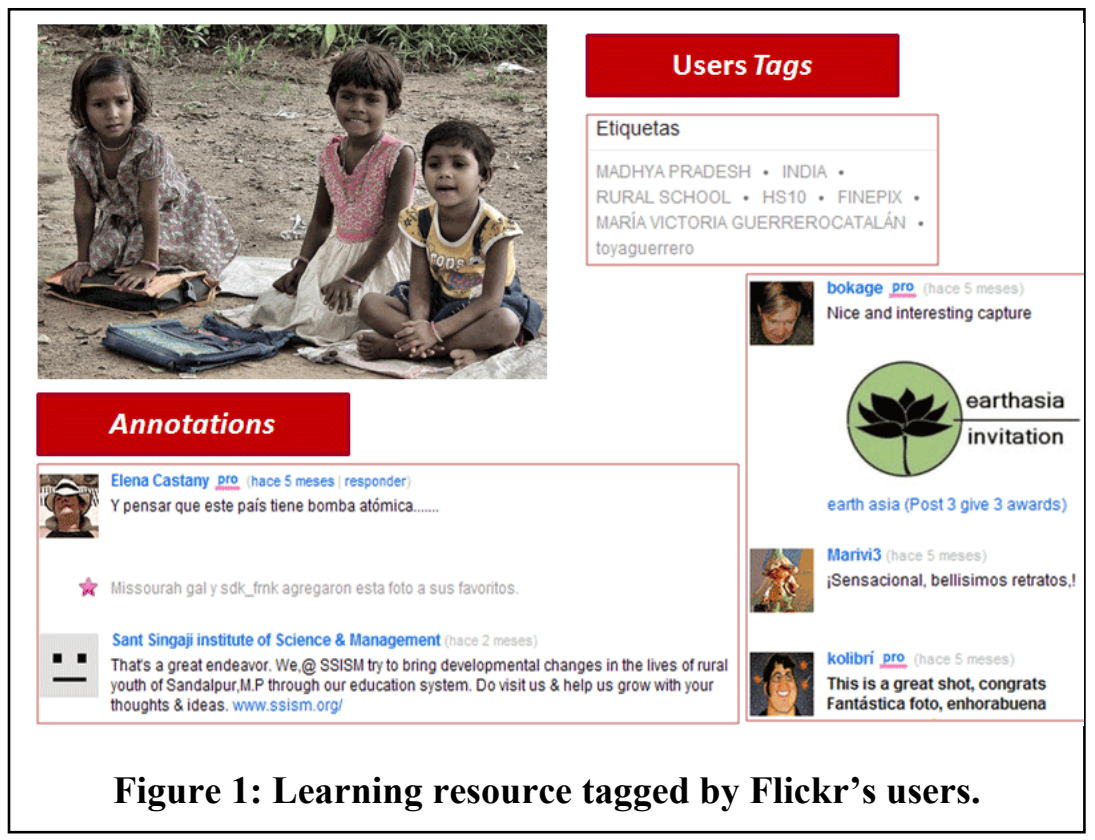

In a similar way, Pinterest provides a collaborative space that allow users to share images through personal boards, organized by subjects, and that reflects their interests, hobbies, etc., promoting participation of the whole community generated from these image collections.

In short, LOs evolution, from a connectivist point of view, is characterized by the introduction of nuances, highly marked by non-formal understanding of the processes and by knowledge generation from the creation of spontaneous links, through the usage of all connectivist tools available now.

\section{Connectivist Tools Integration into CLOs Design}

The new framework of the social Web extend the learning process through a variety of connectivist tools, thus CLOs are no longer just information collections, but also a means for creating and sharing knowledge.

CLOs, as a new version of LOs, emerge from the confluence of the interactions of different users, who contribute to build a CLO's design with an open structure and in constant evolution. At the same time, CLOs still keep their primary quality of learning facilitators but they also acquire new functionalities which involve the use of connectivist tools.

Connectivist tools enrich and enhance the constructivist learning by bringing in new and uncounted possibilities for learners and instructors. Table 2 describes different constructivist and connectivist tools and the opportunities they provide for the collaborative work. 
Table 2: Learning Tools - adapted from Del Moral and Villalustre (2012).

\begin{tabular}{|l|l|l|}
\hline $\begin{array}{c}\text { Tools Function- } \\
\text { ality }\end{array}$ & \multicolumn{1}{|c|}{ Constructivist Tools } & \multicolumn{1}{|c|}{ Connectivist Tools } \\
\hline $\begin{array}{l}\text { Contents and } \\
\text { knowledge con- } \\
\text { struction }\end{array}$ & Inquiry-based and problem-based contents & $\begin{array}{l}\text { Collaborative contents construction and } \\
\text { shared edition through wikies, blogs, } \\
\text { Cmaps tools, etc. } \\
\text { Shared learning experiences through social }\end{array}$ \\
\hline $\begin{array}{l}\text { Interdisciplinary } \\
\text { connections }\end{array}$ & $\begin{array}{l}\text { Problems resolution, projects and applica- } \\
\text { tions which require interdisciplinary con- } \\
\text { nections }\end{array}$ & $\begin{array}{l}\text { CLO itself becomes a connection node } \\
\text { between interdisciplinary information net- } \\
\text { works }\end{array}$ \\
\hline $\begin{array}{l}\text { Collaboration and } \\
\text { group work }\end{array}$ & $\begin{array}{l}\text { Collaborative working through groups } \\
\text { created by the instructor, on the learning } \\
\text { platform }\end{array}$ & $\begin{array}{l}\text { Collaboration through spontaneous con- } \\
\text { nections created over social networks }\end{array}$ \\
\hline Communication & $\begin{array}{l}\text { Different kinds of communication tools } \\
\text { provided by learning systems, such as } \\
\text { chats, e-mail, forum, etc. }\end{array}$ & $\begin{array}{l}\text { Multiple communication tools out of learn- } \\
\text { ing platform, real-time communication } \\
\text { through the use of mobile devices applica- } \\
\text { tions, such as WhatsApp, Line, Tango, and } \\
\text { Viber. }\end{array}$ \\
\hline Assessment & $\begin{array}{l}\text { Teacher and P2P feedback, self- } \\
\text { assessment through organized evaluation } \\
\text { activities. }\end{array}$ & $\begin{array}{l}\text { P2P continuous evaluation and permanent } \\
\text { feedback flow, from the whole commu- } \\
\text { nity, through social networks. }\end{array}$ \\
\hline
\end{tabular}

CLOs enable the development of various learning activities adjustable to different users' context. Thus, one CLO can generate multiple learning situations and itineraries. Similarly, the way they are presented could be modified by all users who access them, in order to adapt them to multiple learning scenarios.

Their interactivity level is directly related to the connectivist tools that users incorporate in the design process, who assume various roles according to the degree of their participation in the different phases of LO design.

\section{Shared Edition and Collaborative Construction of CLOs}

Wikis enable the generation of hypertextual CLOs which can be constantly actualized, so that all users can take the role of coauthors and co-designers, reaching a shared knowledge construction and a collaborative learning process supported by interactions and relationships between communities' members who share diverse ideas, opinions, and experiences (Lending, 2010). These collaborative tools are very effective in organizing group tasks in learning contexts. Among their potential applications we could mention the following (Del Moral, Cernea \& Villalustre, 2007; Raman, Ryan \& Olfman, 2005; Seitzinger, 2006):

- Creating contents collaboratively, knowledge construction, shared CLOs editing and publishing;

- Collaborative research development;

- Collaborative project libraries;

- Shared notebooks and annotations;

- Collaborative thinking technics like brainstorming;

- Communication space between learners and experts; 
- Individual and group evaluation through tasks portfolio;

- Peer to peer reviews.

Wikis focused on shared knowledge construction are ideal to facilitate CLO design. Users can reedit CLOs, amplifying their contents information, providing new examples, illustrating them by new experiences, connecting them with new learning networks, and so forth.

For example, Wikiversity is a free access learning platform, specifically intended to develop collaborative learning projects for different education levels and different knowledge areas (such as Astronomy, Engineering, Architecture, Philosophy, and Geography). In this wiki all users are allowed to build collaborative learning content; they can teach and learn as well, and every user can take part in any learning activity organized in the Virtual Campus.

The following example shows a CLO on "Rural Schools", a subject taught in the degree of Pedagogy from Oviedo University, where the proposed collaborative activities are performed through the use of a wiki (Figure 2).

A wiki is created for each working group, generating small "knowledge cubicles", which are edited and collaboratively designed by students, guided by the subject's tutors. In this example all wikis will have the same structure in order to facilitate interactions between the members of all learning micro-communities formed during the course. Students take on the role of co-designers of the projects developed by each working group, by elaborating new ideas and materials, permanently tutored and in a collaborative way.

Similarly, other group activities and individual activities are proposed through graphical organizers such as mental maps, conceptual maps, and timelines. The following example presents a CLO collaboratively created by students from the same subject mentioned above. Figure 2 shows a concept map about rural school in the global village of the subject "Rural Schools". The concept map consists of concepts and propositions to create a visual CLO.

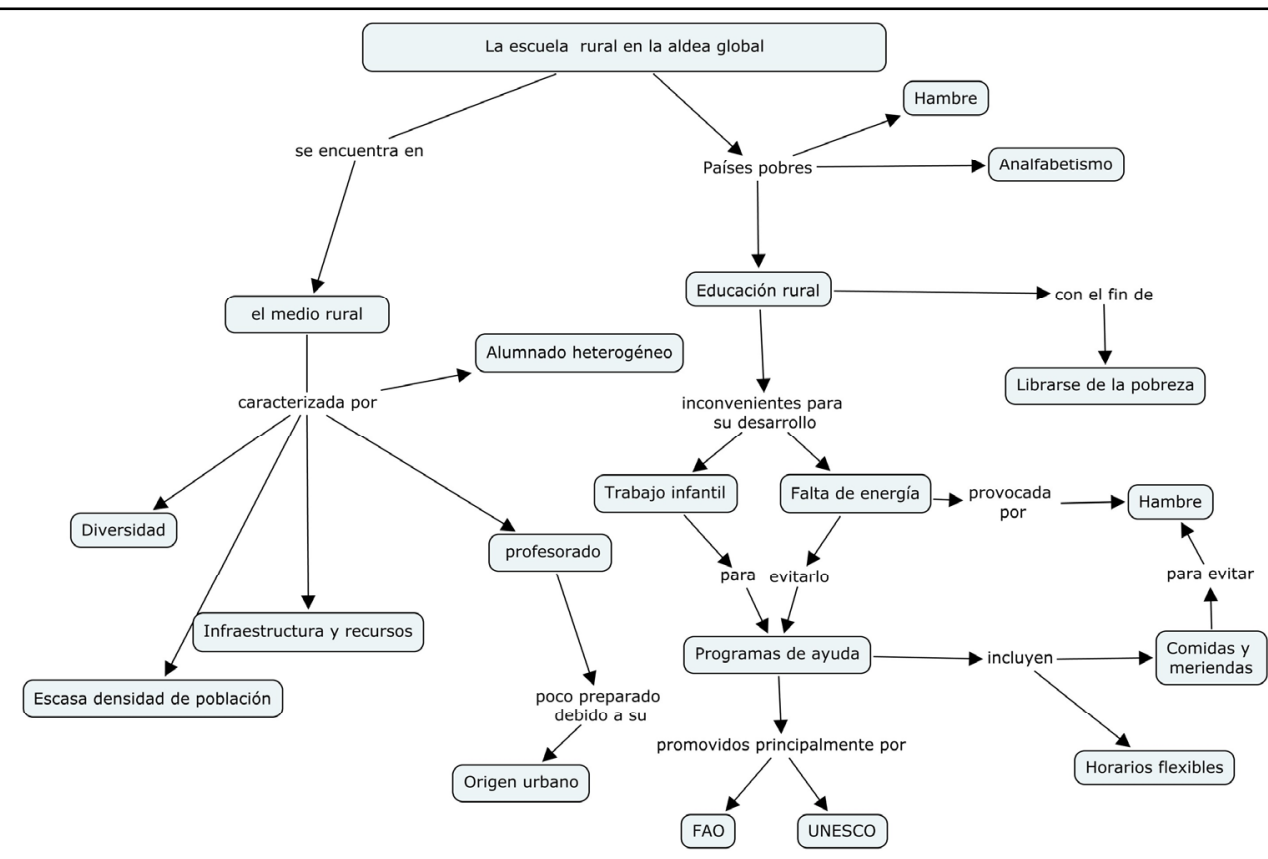

Figure 2: A conceptual map on Rural School. 
Meanwhile, blogs allow users to share their thoughts, considerations, and personal perceptions about educative materials, resources, and learning experiences (Winner, 2003). Their comments trigger the creation of social structures, which facilitate the formation of solid learning communities. Blogs possess various applications in the training and education field, due to their versatility, great simplicity and ease of content publishing. Similar to wikis, blogs are suited to promote interaction between all agents involved in the learning process (Roussinos \& Jimoyiannis, 2011).

\section{Social Classification and Collaborative Annotation}

Folksonomies, such as Flickr for photos sharing or Delicio bookmarking system, provide a collaborative classification of resources through social tagging, and thus they bring into the learning scenario users' personal learning experiences. Furthermore, social tags, assigned to web resources, help classification, rating, and discovering related information (Cernea, Del Moral, \& Labra, 2008; Del Moral, Cernea, \& Villalustre, 2007, 2010). This new generation of CLOs enables all users to add enough descriptive keywords to learning resources in order that they may be reused and shared by others.

Within connectivist learning environments, learning is stimulated from a collaborative point of view, by bringing in alternative ways of working which underline the social dimension of knowledge. Here, interaction and interconnection are favoured for the purpose of collaborative problem resolution and project execution, creating social and collaborative learning spaces (Owen, Grant, Sayers, \& Facer, 2006), where CLO design acquires a new value related to its ability of bringing in learning context and personal meaning.

Personal interactions that emerge through shared annotations enable and encourage collaborative learning and enable users' constant reflection on the relationship between the learning resource and its tag, enhancing the conceptual socialization of CLOs (Del Moral, Cernea, \& Villalustre, 2007).

Similarly, from a socio-constructivist point of view, the use of collaborative tags and social bookmarks originated by users of a virtual community improve CLO management, due to the social structure created. At the same time new social communication modalities and interactions are produced. Social tagging entails interconnections between multiple networks of resources and of users. According to Marlow, Naaman, Davis, and Boyd (2006) these involve:

- Resources connected through links and tags;

- Users belonging to different social networks and connected through the shared tags assigned to learning resources and CLOs;

- Tags which connect CLOs and users, providing semantic information about their contents, evaluation and feedback, based on shared experiences and contextualized applications. Figure 3 shows a CLO, part of Pachyderm project, where users' comments connect resources and people and supply rich feedback.

Collaborative CLO tagging favours the creation of a social and personal learning context. From the connectivist point of view, the shared user's tags bring learning meaning to CLO, promoting the social dimension of on line learning (Estelles, Del Moral, \& Gónzalez, 2010). Users are motivated and involved consciously in the creation of new learning meanings assigned to shared objects, generating in this way a new learning context. 


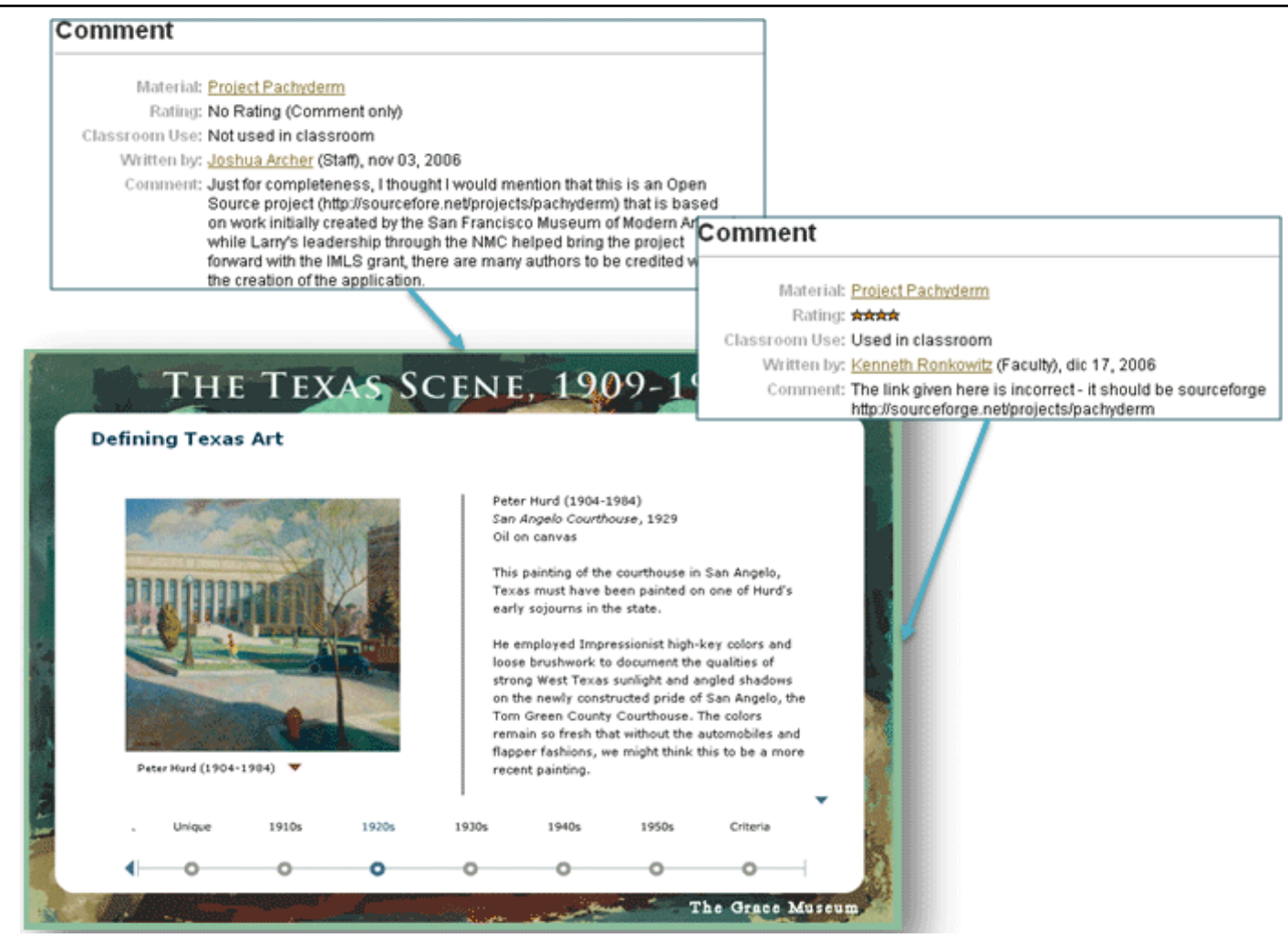

Figure 3: Evaluation, feedback and learning context through users' annotations.

Youtube, Vimeo, etc. enable video publication and users' comments; they can be linked from other web pages or included in blogs and social networks. These kinds of platforms include classification tools, annotation, and evaluation utilities; they show visit statistics and include functionalities for creating and sharing lists of favourites.

In this context, many universities have already created their own channels in Youtube Education, including the University of Oviedo, which activated its own learning space. This enables students to access a shared educative space, where they can watch different audiovisual documents, such as conferences, lectures, master classes, tutorials, and academic events. At the same time, learners can publish their most relevant works, in order to share them with the whole learning community.

Similarly, SlideShare becomes a shared learning space, where various users can host and publish slide presentations with learning value. It allows users to add their annotations and comments, and also to reference or insert slide presentations in an external web page.

\section{Communication Formulas for CLO Interchange}

Social networks like Facebook, Twitter, and Myspace are forms of social connection, based on interactive and dynamic information interchange between users, groups and institutions, in continuous evolution and growth.

Social networks favor the development of different kinds of competences, from basic abilities such as information research and selection to superior cognitive abilities such as collaborative projects elaboration, cooperative problem resolution, capability to organize, planning and schedule elaboration (Alloway \& Alloway, 2012). Figure 4 shows an example of different connectivist tools integration in the CLO design. 


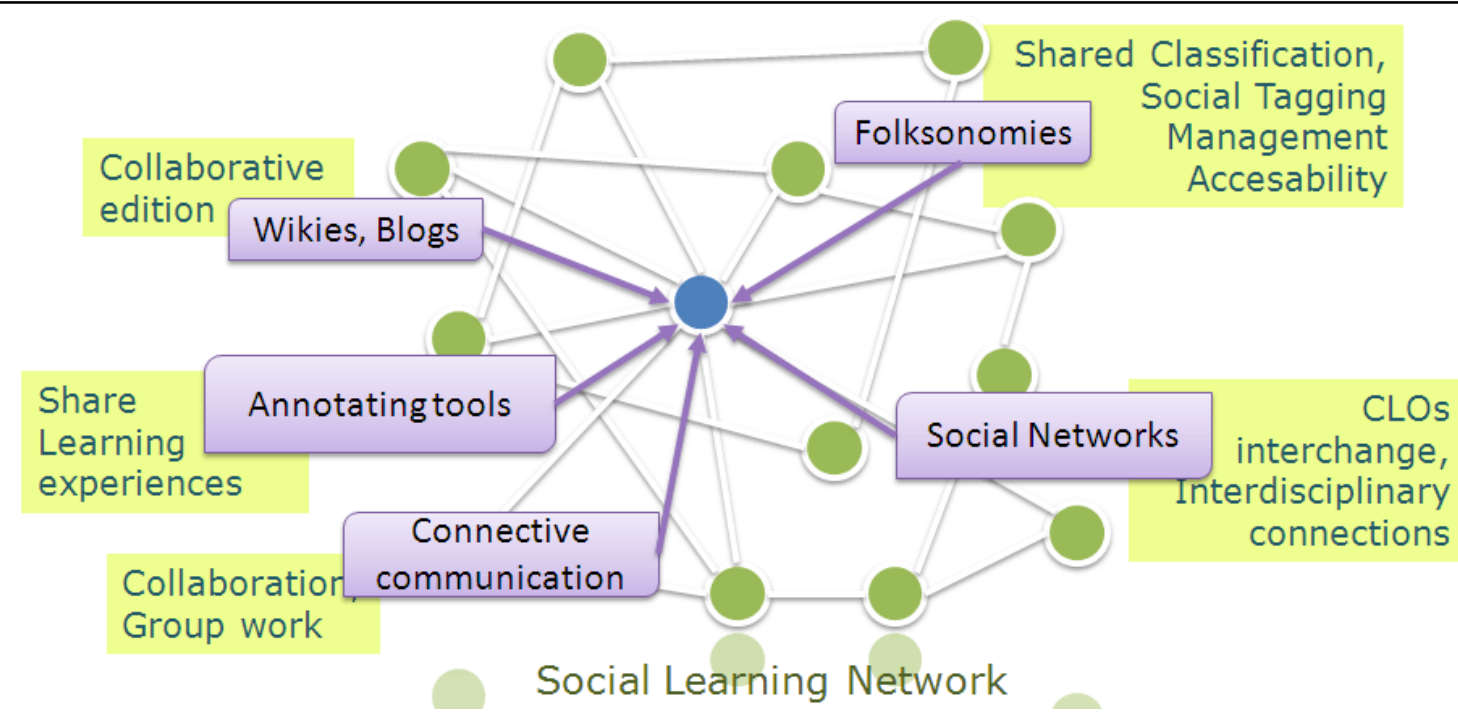

Figure 4: Connectivist tools for CLO open design.

Facebook, with 1.06 billion monthly active users according to statistics on December 31, 2012, is a connectivist tool for exchanging comments on shared resources, such as videos, photos, and links, and also permits communication via mail or chat and video chat. It provides a space where users share their own profile between various groups of people with similar interests. This network connects a broad range of external applications and social tools from very different fields, which can contribute to the collaborative design of CLOs.

As an educational tool, Facebook establishes an online meeting space between experts and learners; it enables users to create groups of people with different levels of privacy and personalized access to other users' personal information. Learning with Facebook entails a greater participation of students, who perceive it as a familiar and meaningful environment and reinforce the connectivist postulates. Thus, when learning with Facebook, capacity to know where knowledge resides is more critical than to maintain knowledge facts, and the ability to see connections between fields, ideas, and concepts is a core skill. Some of the challenges of using Facebook as a pedagogical tool are presented in Rambe and Ng'ambi (2011), where the authors provide a study conducted on students and teachers from the Commerce Faculty, University of Cape Town.

Twitter is a very real connectivist tool which allows users to share short posts and which could find multiple applications in the educational field. As Cohen and Duchan (2012) show in their research, some of Twitter's learning functionalities used as a teaching/learning tool within a group of students could be raising ideas, questions and answers, sharing materials, group work, learning process management through coordinating schedules for submission of assignments, notifications and reminders, and social support, including feedback and encouragement.

All these social networks integrate or connect with manifold applications which allow users to share, publish, and evaluate learning resources and CLOs, providing meaningful feedback.

Another social tool that we would like to mention here is Scribd, which enables users to share and upload different kinds of documents and CLOs (Word, Excel, PowerPoint, pdf documents, etc.). It allows adding comments, classifying and annotating these resources. It integrates connections with the most popular social networks, like Facebook, Twitter, and Buzz, taking advantage of their already created social structures and of their shared knowledge. 
On the other hand, the immediate communication provided by popular social tools. like Skype, Messenger, and Google Talk, promote interaction and interpersonal links in a very fluid way, as all these applications are now available on every device and accessible for all users.

Google Wave brings together the collaborative functionalities of all communication tools described above, creating a shared working space for collaborative projects in real time. Users can synchronously share their desktop and their location in a map, as well as exchange videos, images, and text documents. This is a tool meant specifically for work meetings and decision making within a group.

As Figure 4 shows, connective tools are part of CLOs and allow for users' contributions, favouring transformation and reusability of learning materials, and bring the personal context of each learner into the central point of $\mathrm{LO}$ creative process.

\section{CLOs and Learning Styles}

Within the Connectivist Web, learning content design guidelines are reformulated for their integration into new learning scenarios, and thus enhancing their adaptability to learners' cognitive diversity. Therefore, connectivist learning environments facilitate a readjustment of LOs to the different types of cognitive strategies utilized during the learning and training process. For that purpose, we have to take into account that cognitive styles are really stable features and yet capable to adapt in certain situations, and if we consider this point, the learning process can become more effective (Del Moral \& Villalustre, 2004).

Different surveys have been carried out in order to identify the best didactical formulas and strategies that could stimulate learning in students with different cognitive preferences (Felder, 1996). It seems that these surveys agree when they identify those methodological practices as appropriate for students with a clear cognitive profile (active, reflexive, pragmatical, or theoretical), as Honey and Mumford (1982) show. However, knowledge acquisition doesn't depend only on teaching strategies, or the way information is organized and presented to students, or CLO design, but also on students themselves. Some essential conditions are the way they organize themselves, or the way they develop and construct their own knowledge from CLOs.

Taking this into account, and despite the wide variety of cognitive styles classifications present in the current literature, we adopted the one based on a Honey and Mumford (1982) proposal, where four cognitive styles are identified, and four ways of accessing, processing and designing CLOs respectively are marked out within a connectivist environment (Del Moral \& Villalustre, 2011):

- Active style: learners with a highly active cognitive style are enthusiastic persons, who get excited about new tasks, like new experiences and are constantly looking for new activities;

- Reflexive style: people with a reflexive cognitive type are characterized by caution and discretion; they are observers and keep a distance with other students;

- Theoretical style: logical, perfectionist, and coherent people;

- Pragmatical style: learners with a pragmatic cognitive style like to act quickly when they are attracted by the projects or ideas presented, and especially when they can draw a practical application from their abilities and knowledge.

A large variety of applications provided by Facebook, such as, for example, CityVille, are oriented to collaborative work. CittyVille proposes the construction of a city, which is carried through the resources furnished by the different network members (Figure 5). Even if it is a recreational approach, learning occurs through collaboration. In this case, users with an active cognitive style dynamically grow their city and play important roles, they can even become mayors. Thus, reflexive users value necessities and prices, pragmatic ones carry out their work depending 


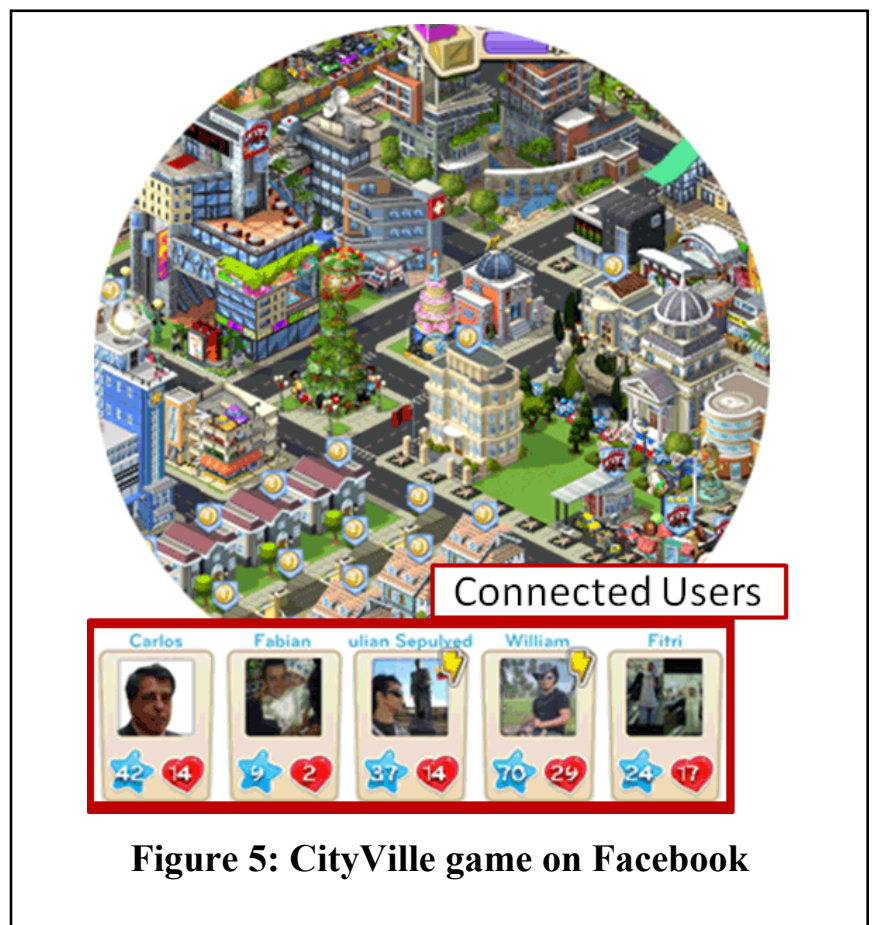

on the advantages, and theoretical users search formulas that could guarantee the stability of the city. In all these cases the connective intelligence is conductive.

So, through CLO design, we can tend to the cognitive diversity of students, by activating the different cognitive mechanisms (like experimentation, action, reflection, and theorizing) which allow them to acquire new knowledge.

On this basis we have elaborated some guidelines for CLO design (Table 3), with the purpose of enabling users to construct knowledge in a connectivist manner, meeting their own cognitive preferences.

Table3: Guidelines for the design of CLOs adapted to users' learning styles

\begin{tabular}{|c|c|c|c|c|c|}
\hline \multirow[b]{2}{*}{$\begin{array}{l}\text { LEARNING } \\
\text { STYLES }\end{array}$} & \multicolumn{5}{|c|}{ KEY ELEMENTS OF CLOS } \\
\hline & $\begin{array}{l}\text { The use of connec- } \\
\text { tive tools }\end{array}$ & $\begin{array}{l}\text { Users' paper in } \\
\text { the CLO design }\end{array}$ & $\begin{array}{l}\text { CLO presenta- } \\
\text { tion and con- } \\
\text { tents organiza- } \\
\text { tion }\end{array}$ & $\begin{array}{l}\text { Type of activities } \\
\text { included in CLO }\end{array}$ & $\begin{array}{l}\text { Evaluation } \\
\text { component of } \\
\text { CLO }\end{array}$ \\
\hline $\begin{array}{l}\text { Active (users who } \\
\text { are fully involved } \\
\text { in new experi- } \\
\text { ences) }\end{array}$ & $\begin{array}{l}\text { Design process based } \\
\text { on an active dialog } \\
\text { through chats, video } \\
\text { conferences... } \\
\text { High level of interac- } \\
\text { tivity through links } \\
\text { which enable explo- } \\
\text { ration and investiga- } \\
\text { tion, or through simu- } \\
\text { lations and other } \\
\text { applications which } \\
\text { require users' partici- } \\
\text { pation }\end{array}$ & $\begin{array}{l}\text { Their social and } \\
\text { communicative } \\
\text { abilities allow } \\
\text { this kind of users } \\
\text { to lead the proc- } \\
\text { ess. }\end{array}$ & $\begin{array}{l}\text { Creative infor- } \\
\text { mation presenta- } \\
\text { tions which } \\
\text { involve learners } \\
\text { to discover its } \\
\text { structure } \\
\text { through naviga- } \\
\text { tion maps. }\end{array}$ & $\begin{array}{l}\text { Oriented to prob- } \\
\text { lems resolution } \\
\text { Meant to assume } \\
\text { roles and make } \\
\text { representations } \\
\text { through debates, } \\
\text { forum, blogs, } \\
\text { wikis... }\end{array}$ & $\begin{array}{l}\text { Oriented to } \\
\text { generation of } \\
\text { ideas and } \\
\text { problems } \\
\text { resolution... }\end{array}$ \\
\hline
\end{tabular}




\begin{tabular}{|c|c|c|c|c|c|}
\hline $\begin{array}{l}\text { Reflexive (they } \\
\text { like to consider } \\
\text { and observe new } \\
\text { experiences from } \\
\text { different points } \\
\text { of view) }\end{array}$ & $\begin{array}{l}\text { Creative communica- } \\
\text { tion through confront } \\
\text { complementary ap- } \\
\text { proaches using blogs, } \\
\text { social bookmarks and } \\
\text { tools that enable crea- } \\
\text { tion of shared web } \\
\text { page. } \\
\text { Contents manipula- } \\
\text { tion is permitted for } \\
\text { its re-edition, adapta- } \\
\text { tion and update. }\end{array}$ & $\begin{array}{l}\text { Their capacity to } \\
\text { collect data and } \\
\text { to investigate, } \\
\text { designate this } \\
\text { type of users as } \\
\text { analysts. }\end{array}$ & $\begin{array}{l}\text { Attractive con- } \\
\text { tents presenta- } \\
\text { tion which } \\
\text { stimulates re- } \\
\text { flection. With a } \\
\text { structure which } \\
\text { facilitate infor- } \\
\text { mation search. }\end{array}$ & $\begin{array}{l}\text { Aimed to promote } \\
\text { investigation and } \\
\text { analysis } \\
\text { Oriented to com- } \\
\text { paring other } \\
\text { points of view and } \\
\text { to reflecting on } \\
\text { the comments of } \\
\text { other users ... }\end{array}$ & $\begin{array}{l}\text { Focused on } \\
\text { observation, } \\
\text { reflection and } \\
\text { detailed } \\
\text { analysis. }\end{array}$ \\
\hline $\begin{array}{l}\text { Pragmatically } \\
\text { (their strong } \\
\text { point is the appli- } \\
\text { cation of ideas } \\
\text { and acquired } \\
\text { knowledge) }\end{array}$ & $\begin{array}{l}\text { Interaction for practi- } \\
\text { cal approaches sup- } \\
\text { ported by collabora- } \\
\text { tive software like } \\
\text { wikis, cmap-tools, } \\
\text { mind-mapping, etc. } \\
\text { Application and con- } \\
\text { textualization of con- } \\
\text { tents is enabled by } \\
\text { the use of flexible } \\
\text { tools. }\end{array}$ & $\begin{array}{l}\text { Their practice- } \\
\text { oriented nature } \\
\text { leads them to } \\
\text { establish guide- } \\
\text { lines that ensure } \\
\text { the applicability. }\end{array}$ & $\begin{array}{l}\text { Dynamic inter- } \\
\text { face which fa- } \\
\text { cilitates CLO } \\
\text { execution, intui- } \\
\text { tive and clear } \\
\text { organization of } \\
\text { contents }\end{array}$ & $\begin{array}{l}\text { Designed to favor } \\
\text { practical applica- } \\
\text { tions and tasks } \\
\text { execution } \\
\text { Addressed to the } \\
\text { elaboration of } \\
\text { action planning } \\
\text { through video- } \\
\text { chat and shared } \\
\text { whiteboard. }\end{array}$ & $\begin{array}{l}\text { Requires the } \\
\text { execution of } \\
\text { practical tasks } \\
\text { through simu- } \\
\text { lations, role } \\
\text { play games, } \\
\text { etc. }\end{array}$ \\
\hline $\begin{array}{l}\text { Theoretical (us- } \\
\text { ers who adapt } \\
\text { and integer their } \\
\text { own observations } \\
\text { into logical and } \\
\text { complex theories) }\end{array}$ & $\begin{array}{l}\text { Collaborative con- } \\
\text { struction of concep- } \\
\text { tual bases and theo- } \\
\text { ries from distribution } \\
\text { lists, forum, etc. } \\
\text { Links and resources } \\
\text { are provided by the } \\
\text { use of social book- } \\
\text { marking which fa- } \\
\text { vour analysis. }\end{array}$ & $\begin{array}{l}\text { Their commit- } \\
\text { ment with solid } \\
\text { theoretical as- } \\
\text { sumptions as- } \\
\text { signs them the } \\
\text { role of connector } \\
\text { between theory } \\
\text { and practice. }\end{array}$ & $\begin{array}{l}\text { Presentation of } \\
\text { contents leads to } \\
\text { analysis. Their } \\
\text { logical sequence } \\
\text { eases CLOs' } \\
\text { exploration and } \\
\text { understanding. }\end{array}$ & $\begin{array}{l}\text { Based on concepts } \\
\text { analysis and theo- } \\
\text { ries } \\
\text { Focused on col- } \\
\text { lecting informa- } \\
\text { tion through spe- } \\
\text { cialized search } \\
\text { engines and data } \\
\text { bases... }\end{array}$ & $\begin{array}{l}\text { Requests the } \\
\text { demonstration } \\
\text { of all con- } \\
\text { cepts and } \\
\text { formulated } \\
\text { theories }\end{array}$ \\
\hline
\end{tabular}

Connectivist learning scenarios offer many possibilities to perform different kinds of training activities, since they allow the learning process to be adapted to users' cognitive styles. This way, the mechanisms for acquiring, storing, and reusing CLOs are facilitated. Some users will prefer a specific presentation which adapts itself better to their cognitive preferences when the contents of the CLO are shown, as detailed in Table 3.

The incorporation of different levels of interactivity in CLOs design meets the training needs of the large diversity of cognitive styles. For example those users with a theoretical or reflexive style may require more links in order to access a greater volume of information so they can understand all the dimensions of the proposed subject (Del Moral \& Villalustre, 2004).

CLOs have given rise to new participation formulas through which emerge new learning resources that enforce the users' approaches, who assume different roles according to their cognitive preferences. Thus, users with an active learning style will tend to lead projects assuming a 
greater part of the responsibility, while users with a pragmatic style will grant greater importance to the applicability of the activities proposed by the CLOs. For this purpose, they will use different digital tools which favour collaboration as a mean for the connectivist learning development.

Nevertheless, users could be conditioned by the type of activities proposed by the CLOs. In this way, users with a pragmatic learning style will opt for those tasks based on practical applications, while theorist ones will choose demonstration of concepts and principles. In the same way, users with an active cognitive style will tend to select problem resolution, while reflexive users will focus on analysis and research.

The different types of users and their individual features set specific ways of learning which could be conditioned by CLO singularities. Therefore, evaluation formulas which measure the level of acquired competence should take into account these cognitive peculiarities. Thus, users with a dominant pragmatic style will require evaluations focused on simulations or role-playing games, where the applicability of theoretical content is a priority, while for users with a dominant theoretical cognitive type, evaluation will be more oriented towards concept analysis, theories, laws, etc. Similarly, users with an active style will focus on ideas generation, and those with a reflexive one will opt for observation and analysis.

Similarly, when planning and designing activities in connectivist learning scenarios, we must take into account these different approaches towards the wide variety of tools provided by the Connectivist Web. Thereby, active users require immediate communication in order to organize and lead working groups, through social tools like chat, video-chat, and instant messaging, while reflexive ones opt for an asynchronous communication through blogs, social bookmarks, etc., which allow them to carry out deliberate and thoughtful analysis.

Thus, when designing CLOs it is convenient to take into account the users' cognitive preferences since this fact will favour the success of the projected tasks. Consequently, appropriate learning spaces and resources are required to promote and to attend to the diversity of learning styles.

Therefore it is necessary to:

- Generate CLOs which involve a cyclic learning process, based on experimentation, action, reflation and theorizing. This will promote the development of different skills and competences, according to the users' cognitive preferences;

- Create CLOs that accentuate participation and interaction between users, with the purpose of favouring the collaborative knowledge construction from users' contributions, taking advantage of their cognitive diversity.

A good example of this kind of practices is the Gameproject implemented by Del Moral and Villalustre (2007). During this project students were required to design their own intervention project oriented to the social-cultural and educative development in a disadvantaged rural area, including ludic elements, such as videogames. With this proposed task the development of the four learning styles presented in this article (active, reflexive, pragmatic, and theorist) was achieved, as the students were invited to collaboratively reflect and theorize on growth actions. To this purpose, they had to use different kinds of connective tools for communication and to obtain the group interaction and for the publication of their projects through wikis and blogs and also for search and share multimedia resources in YouTube, Picasa, etc.

Gameproject represented a great opportunity to formulate CLOs which meet the cognitive diversity of students, through its tasks that promote connectivist learning. 


\section{Conclusion}

The use of the Web 2.0 tools (like wikis, weblogs, and folksonomies) enables a large number of connectivist activities and learning practices. From this point of view, in the new learning landscape, shared learning experiences make possible informal learning from spontaneous connections between open networks which are undergoing constant change.

This new learning scenario promotes qualitative change, redefining learning as a social process and introduces alternative ways of working, which underline the social dimension of knowledge constructed from LOs. CLOs drive the creation of virtual learning communities which favour interaction and interconnections between users and learning resources and enable the performance of collaborative projects. For these purposes, new skills and abilities are required:

- Ability to identify relevant information and relevant connections through learning resources networks, which are continuously growing;

- Ability to recognize the changes of the learning landscape, generated by the newly incorporated information;

- Ability to connect specialized information nodes, and thus contribute to knowledge network creation;

- Capacity to feedback and maintain connections, to ensure the continuity of connective processes;

- Ability to make decisions at any time, choosing content and significant itineraries within a learning context in constant change;

- Ability to exploit, cultivate and improve the cognitive capacity of learning communities, ensuring an effective knowledge flow.

Thus, in a connectivist learning landscape, users bring into play different abilities and competencies, as well as various methodological strategies closely related to the subjects' individual features. In this new context, learning styles acquire a great relevancy, especially for CLO design, which should be adapted to users' cognitive diversity. New connective resources and CLOs contribute to contextualize learning and endow it with a great significance through multiple learning experiences and the situations they provide. All this enables multiple learning contexts which take into account the different cognitive strategies for knowledge acquisition in collaboration.

CLOs design, adapted to the cognitive diversity, enable users to control and manage the learning resources and the learning process, in a personalized space which promote the collaborative knowledge construction. As Béres and Turcsányi-Szabó (2010) show, collaborative content creation allows users to be co-authors and active participants in the learning process. This way, through interaction and connections between users and through collaborative tools (such as wikis and social networks), it is possible to generate connective knowledge based on real experiences.

The new framework proposed by the emergent Web 2.0 tools and the social networks, facilitates the connection of multiple users with different cognitive styles, and this offers the opportunity to interchange experiences and enrich interactions, helping the learning transference and the collaborative knowledge construction, generating the CLOs.

The success of the CLOs design, oriented to formative practices, is based on both the suitable selection of the collaborative tools (such as wikis, blogs, social media ...) and on their adaptability to the users' cognitive diversity. 


\section{References}

Alloway, T. P., \& Alloway, R. G. (2012). The impact of engagement with social networking sites (SNSs) on cognitive skills. Computers in Human Behavior, 28(5), 1748-1754.

Béres, I., \& Turcsányi-Szabó, M. (2010). Added value model of collaboration in higher education. Interdisciplinary Journal of E-Learning Objects, 6, 203-215. Retrieved from http://www.ijello.org/Volume6/IJELLOv6p203-215Beres723.pdf

Brown, J.S., \& Duguid, P. (1991). Organization science organizational learning and communities-ofpractice: Toward a unified view of working, learning, and innovation. Organization Science, 2(1), 4057.

Cernea, A., Del Moral, M. E., \& Labra, J. E. (2008). SOAF: Semantic indexing system based on collaborative tagging. Interdisciplinary Journal of Knowledge and Learning Objects, 4, 137-149. Retrieved from http://www.ijello.org/Volume4/IJELLOv4p137-149Cernea.pdf

Cohen, A., \& Duchan, G. (2012). The usage characteristics of Twitter in the learning process. Interdisciplinary Journal of E-Learning Objects, 8, 149-163. Retrieved from http://www.ijello.org/Volume8/IJELLOv8p149-163Cohen0808.pdf

Del Moral, M. E., \& Cernea, A. (2005). Design and evaluate learning objects in the new framework of the semantic web. In A. Méndez-Vilas, B. González-Pereira, J. Mesa González, \& J. A. Mesa González (Eds.), Recent research developments in learning technologies (pp.1032-1036). Badajoz: Formatex.

Del Moral, M. E., Cernea, A., \& Villalustre, L. (2007, September). Contributions of the Web 2.0 to collaborative work around learning objects. Post-proceedings of the International Conference on Technology, Training and Communication. Salamanca, Spain. Retrieved from http://sunsite.informatik.rwth-aachen.de/Publications/CEUR-WS/Vol-361/paper13.pdf

Del Moral, M. E., Cernea, A., \& Villalustre, L. (2010). Learning objects 2.0: A new generation of content in context connectivism. Revista de Educación a Distancia (RED), 25, 1-11.

Del Moral M. E., \& Villalustre, L. (2004). Indicadores de calidad en la docencia virtual: adaptación de los entornos a la diversidad cognitiva de los estudiantes [Quality indicators in virtual teaching: Adaptation of the environments to the cognitive diversity of students]. Revista Aula Abierta, 84,155-172.

Del Moral M. E., \& Villalustre, L. (2007). Gameproject: A multimedia presentation of a joint project for a degree in education. In G. Richards (Ed.), Proceedings of World Conference on E-Learning in Corporate, Government, Healthcare, and Higher Education 2007 (pp. 2005-2012). Chesapeake, VA: AACE.

Del Moral M. E., \& Villalustre, L. (2011). Good teaching practice and quality indicators for virtual and blended learning: Project Matrix. International Journal of Digital Literacy and Digital Competence (IJDLDC), 2(1), 37-51.

Del Moral, M. E., \& Villalustre, L. (2012). Medios sociales: comunicación y desarrollo de la inteligencia conectiva en red [Social media: Communication and development of the connective intelligence network]. In J. Martínez \& I. Solano (Coords.), Comunicación y relaciones sociales de los jóvenes en la red (pp. 125-136). Alcoy: Marfil.

Downes, S. (2005). e-Learning 2.0. eLearn Magazine, 10(17). Retrieved from http://elearnmag.acm.org/featured.cfm?aid $=1104968$

Downes, S. (2007a, June). An introduction to connective knowledge. In T. Hug (Ed.), Media, knowledge \& education - Exploring new spaces, relations and dynamics in digital media ecologies. Proceedings of the International Conference. Innsbruck: University Press.

Downes, S. (2007b). What connectivism is. Retrieved from web http://halfanhour.blogspot.com/2007/02/what-connectivism-is.html

Duffy, T., \& Cunningham, D. (1996). Constructivism: Implications for the design and delivery of instruction. In D. H. Jonassen (Ed), Handbook of research for educational communications and technology (pp. 170-198). New York: Simon and Schuster. 
Duffy, T., \& Jonassen, D. (Eds.). (1992). Constructivism and the technology of instruction: A conversation. Hillsdale, NJ: Lawrence Erlbaum Associates.

Elgort, I., Smith, A. G., \& Toland, J. (2008). Is wiki an effective platform for group course work? Australasian Journal of Educational Technology, 24(2), 195-210.

Ertmer, P. A., \& Newby, T. J. (1993). Behaviorism, cognitivism, constructivism: Comparing critical features from an instructional design perspective. Performance Improvement Quarterly, 6(4), 50-72

Estelles, E., Del Moral, M. E., \& González, F. (2010). Social bookmarking tools as facilitators of learning and research collaborative processes: The Diigo Case. Interdisciplinary Journal of Knowledge and Learning Objects, 6, 175-191. Retrieved from http://www.ijello.org/Volume6/IJELLOv6p175191Estelles683.pdf

Felder, R. M. (1996). Matters of style. Principles and applications of four learning style models. ASEE Prism, 6(4), 18-23. Retrieved from http://www.ncsu.edu/felderpublic/Papers/LS-Prism.htm

Hannafin, M. J., Hannafin, K., Land, S. M., \& Oliver, K. (1997). Grounded practice and the design of constructivist learning environments. Educational Technology Research and Development, 45(3), 101117.

Honey, P., \& Mumford, A. (1982). Manual of learning styles. London: P. Honey.

Koivunen, M., \& Swick, R. (2003). Collaboration through annotations in the semantic web. In S. Handschuh \& S. Staab (Eds.), Annotation for the semantic web (pp. 46-60). Amsterdam: IOS Press

Lending, D. (2010). Using a wiki to collaborate on a study guide. Journal of Information Systems Education, 20(1), 5-13.

Marlow, C., Naaman, M., Davis, M., \& Boyd, D. (2006). HT06, Tagging Paper, Taxonomy, Flickr, Academic Article, To Read. Proceedings of the Seventeenth Conference on Hypertext and Hypermedia (pp. 31-40). New York: ACM Press.

Owen, M., Grant, L., Sayers, S., \& Facer, K. (2006). Social software and learning. Retrieved from http://www.futurelab.org.uk/research/opening_education.htm

Raman, M., Ryan, T., \& Olfman, L. (2005). Designing knowledge management systems for teaching and learning with wiki technology. Journal of Information Systems Education (JISE), 16(3), 311-320.

Rambe, P., \& Ng'ambi, D. (2011). Towards an information sharing pedagogy: A case of using Facebook in a large first year class. Informing Science: the International Journal of an Emerging Transdiscipline, 14, 61-89. Retrieved from http://www.inform.nu/Articles/Vol14/ISJv14p061-089Rambe579.pdf

Roussinos, D., \& Jimoyiannis, A. (2011). Blended collaborative learning through a wiki-based project: Case study on students' perceptions. International Journal of Digital Literacy and Digital Competence (IJDLDC), 2(3), 15-30.

Rumelhart, D. E., \& Norman, D. A. (1985). Representation of knowledge. In A. M. Aitkenhead \& J. M. Slack (Eds.), Issues in cognitive modelling. London: Lawrence Earlbaum.

Seitzinger, J. (2006, July). Be constructive: Blogs, podcasts, and wikis as constructivist learning tools. Learning Solutions Magazine. Retrieved from http://www.learningsolutionsmag.com/articles/220/beconstructive-blogs-podcasts-and-wikis-as-constructivist-learning-tools/page4

Siemens, G. (2005, January). Connectivism: A learning theory for the digital age. International Journal of Instructional Technology \& Distance Learning, 2(1). Retrieved from http://www.itdl.org/Journal/Jan_05/article01.htm

Siemens, G. (2006). Knowing kowledge. Retrieved from http://www.knowingknowledge.com/

Siemens, G. (2008). Connectivism and connective knowledge. Retrieved from http://www.youtube.com/watch?v=a5-Wk2cwb68\&lr=1

Stephenson, K. (1998). What knowledge tears apart, networks make whole. Internal Communication Focus, 36. Retrieved from http://www.netform.com/html/icf.pdf 
Wiley, D. (2004, April). The Reusability Paradox. Connexions Web. Retrieved from http://cnx.org/content/m11898/1.18/

Wilson, B. (1996). What is a constructivist learning environment? In B. Wilson (Ed.), Constructivist learning environments: Case studies in instructional design (pp. 3-7). Englewood Cliffs, NJ: Educational Technology Publications.

Winner, D. (2003, May). What makes a weblog a weblog? Retrieved from http://blogs.law.harvard.edu/whatMakesAWeblogAWeblog

Wittrock, M. C. (1974). Learning as a generative process. Educational Psychologist, 11, 87-95.

\section{Biographies}

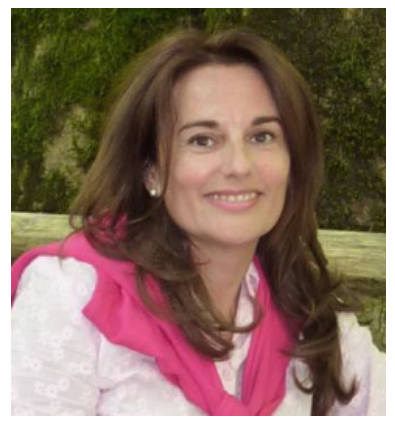

M. Esther del Moral is Professor of Information \& Communication Technologies applied to Education. Faculty of Teacher Training and Education. University of Oviedo (Spain). Director of TECNA Research Team (Technology and Learning). Member of Committee of Innovation (University of Oviedo). Virtual tutor in "Education in Rural Context", in the Shared Virtual Campus of Group Nine Universities (G9) (Spain). Research Areas: e-learning, ICT, Digital Literacy, Video games, Web 2.0. Co-author: (2009). Modalities of Telemathic Learning and Inter-university Results, Extrapolated to Blended Learning. Participation in Internacional Congresses. Principal Researcher in Competitive Projects. Visitor lecturer in University of Calgary (Canada), Poutiers (France), Freiburg (Germany), ITD Genova (Italy).

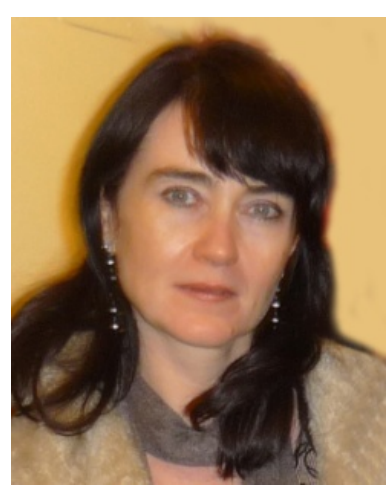

Ana Cernea graduated in Pure Mathematics from the University of Bucharest in 1989 and received the M.S. degree in Computer Science from Oviedo University, Spain in 2006. Presently she is a member of the Mathematics Department of the University of Oviedo and teaches Linear Algebra and Geometry and Mathematics for Engineers in Polytechnics School of the University of Oviedo. She develops an intensive research work in Image Processing and Pattern Recognition fields.

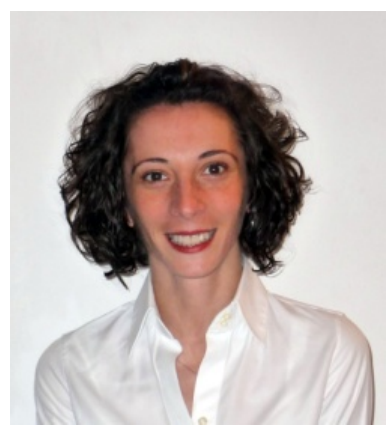

Lourdes Villalustre has a $\mathrm{PhD}$ from the University of Oviedo and Professor of ICT for Education in the Faculty of Teacher Training and Education. She teaches at several virtual learning courses for university teachers internationally. She has participated in several competitive research projects funded by different agencies and institutions. She has worked as a guest researcher at several universities and Centers (Montreal, Canada; Genova, Italy; University of Lisbon, Portugal; Lima, Peru, etc.). She is the author of several books and has written several book chapters and co-authored numerous articles as well as Spanish and foreign journals. 